\title{
Bringing the User Back in the Building: An Analysis of ESG in Real Estate and a Behavioral Framework to Guide Future Research
}

\author{
Shirley Kempeneer ${ }^{1,2, *}$, Michaël Peeters ${ }^{1,3}$ and Tine Compernolle ${ }^{3}$ \\ 1 Antwerp Management School, LAMMP Chair on Behavioral Insights in Real Estate, Boogkeers 5, \\ 2000 Antwerp, Belgium; Michael.Peeters@student.ams.ac.be \\ 2 Tilburg Law School, Professor Cobbenhagenlaan 221, Tilburg University, 5037 DE Tilburg, The Netherlands \\ 3 Faculty of Business and Economics, University of Antwerp, Prinsstraat 13, 2000 Antwerp, Belgium; \\ tine.compernolle@uantwerpen.be \\ * Correspondence: Shirley.kempeneer@ams.ac.be; Tel.: +32-48599-4617
}

Citation: Kempeneer, S.; Peeters, M.; Compernolle, T. Bringing the User Back in the Building: An Analysis of ESG in Real Estate and a Behavioral Framework to Guide Future Research. Sustainability 2021, 13, 3239. https://doi.org/10.3390/su13063239

Academic Editor: Chunjiang An

Received: 19 February 2021

Accepted: 10 March 2021

Published: 15 March 2021

Publisher's Note: MDPI stays neutral with regard to jurisdictional claims in published maps and institutional affiliations.

Copyright: (c) 2021 by the authors. Licensee MDPI, Basel, Switzerland. This article is an open access article distributed under the terms and conditions of the Creative Commons Attribution (CC BY) license (https:/ / creativecommons.org/licenses/by/ $4.0 /)$.

\begin{abstract}
Investors are currently obliged to take environment, social, and governance (ESG) issues into consideration as part of their fiduciary duty. As such, it becomes increasingly important to identify sustainable investments that also hold financial value. A sector where this is especially underdeveloped is real estate. This has a lot to do with the obfuscated conceptualization of ESG. The article identifies key gaps in the literature and practice and provides a framework to further the understanding of how ESG factors can add societal and financial value in the real estate sector. A key premise of the article is that the user in the building is grossly overlooked. Drawing on insights from behavioral social science and environmental psychology, the paper explains the role of the user in improving buildings' ESG, also taking into account the investment value. To conclude, the article makes the case that the transition to user-centered smart real estate is the solution to improving both the environmental (E) and social (S) sustainability of buildings, as well as their investment value. Therefore, practitioners and academics are encouraged to critically evaluate and contextualize the ESG framework they are using as well as the extent to which users are considered and smart technology is employed.
\end{abstract}

Keywords: ESG; sustainable finance; smart real estate; sustainable real estate; user wellbeing; social sustainability; environmental sustainability

\section{Introduction}

In the last two decades, promulgated by the financial crisis and the Paris Climate Agreement, global concerns about climate change and business ethics have fueled interest in environmental, social, and governance (ESG) issues and their associated risks [1]. However, interest in non-financial information and notions of socially responsible investment (SRI) and corporate social responsibility (CSR) have been around much longer, gaining momentum due to historical events, such as civil and women's rights movements [2]. The term ESG was coined in a 2004 United Nations (UN) report titled "Who Cares Wins", aimed at raising awareness about the importance of environmental, social, and corporate governance issues for financial markets. A year later, the UN Environmental Program's Finance Initiative (UNEP-FI) provided evidence on the financial relevance of ESG issues and promulgated the use of ESG information in investment decisions. Moreover, UNEPFI's 2019 report on "fiduciary duty in the 21st century" describes how ESG issues are increasingly integrated into regulatory and legal requirements for institutional investors, warning that investors who fail to take ESG into account will likely face legal challenges [3].

As such, a dual purpose can be identified in the use of ESG. Initially, investors focused on the value of ESG issues in and of themselves, stressing the environmental and social costs and benefits. Over time, other investors became interested in ESG from a more 
financially focused position, where sustainability is taken into account more rationally in function of its material costs and benefits. Eccles, Lee, and Stroehle (2020) call these two approaches the values-based, and value-based approach, respectively. Although analytically distinct, the two approaches often coincide in practice, where both the societal and financial benefits of sustainable investment are deemed important. Today, regardless of more altruistic or pure financial motives, investors increasingly have no way around incorporating ESG considerations in their investment decisions, as it has become an almost global legal prerequisite [3]. As such, investors and their clients are increasingly interested in finding profitable sustainable investments.

Over the past years, a substantial body of research has focused on understanding the relationship between financial and nonfinancial investment performance. The consensus to date is that paying attention to ESG issues can generally lead to better financial performance [4-8], although this body of literature is rife with uncertainty. A sector where this relationship is particularly unclear is real estate. When it comes to real estate investments and asset management, there are many mixed and contradictory findings. The catchall statement that any improvement in ESG would automatically lead to higher investment value is untrue. Conclusions range from finding no correlation at all between ESG and financial performance [9-11], to mixed results [12-14], with several cases even showing an inverse relationship $[5,15,16]$. However, some studies do give evidence of a positive relationship, often emerging in the long run $[17,18]$. To complicate the matter further, it is in many cases still unclear what it means to improve ESG factors in the first place.

This is for a large part due to a lacking universal conceptualization of ESG and a divergence in ESG measurement practices among rating agencies, practitioners, and academics $[19,20]$. This divergence can be traced back to the diverging value and valuebased philosophies mentioned earlier. Depending on the indicator selection, measurements, and weights applied, different assessments of the same company's ESG performance may diverge [2]. A better contextualization of findings is necessary to determine which interventions can improve ESG factors in the first place, and secondly which of those hold additional financial benefits for investors. Most of the literature to date has neglected the role of the user of the building in all of this. As such, this paper fills the knowledge gap of how user behavior might affect both the ESG value of real estate as well as its investment value.

The remainder of this paper first reviews the general conceptualization of ESG factors, discussing the diverging measurement practices of ESG issues and strides made towards standardization. In the third section, the paper looks at ESG in real estate, a sector grossly understudied to date, and lays bare an important lacuna in ESG considerations for real estate investment, namely, that the user of the building is not at all taken into consideration. The paper draws on behavioral social science and environmental psychology to explain the role of the user in achieving environmentally and socially sustainable buildings, also taking into account the financial value this may hold for investors. For instance, environmental improvements in buildings are currently mainly sought through technical means. However, behavioral social science shows that the extent to which these technical means can improve building performance is highly dependent on user behavior [21]. As such, this paper suggests incorporating user wellbeing in the conceptualization of the social component of ESG for real estate rather than simply looking at compliance with labor laws and human rights. More broadly, the paper argues that social and environmental sustainability are intricately intertwined and cannot be dealt with separately. The third section concludes by making the case that the transition to smart real estate that is user-centered is the solution to improving both the environmental (E) and social (S) sustainability of buildings (ESG factors) as well as the investment value of real estate. It concludes with suggestions for future research and key recommendations for real estate professionals. Governance aspects of ESG criteria are not further taken into explicit consideration in this paper, although often implicitly included. 


\section{The Current State of ESG Measurement}

Environmental, social, and governance measurements have significantly increased in usage due to growing concerns for environmental and societal problems. They increasingly influence financial decisions, with potentially far-reaching effects on asset prices and corporate policies $[5,10]$. ESG rating agencies offer investors a way to screen companies for ESG performance in a similar way to how credit ratings allow investors to screen companies for creditworthiness. However, despite this similarity, there are important differences between ESG ratings and credit ratings. The key difference is that while creditworthiness is relatively clearly defined as the probability of default, there are no commonly agreed-upon measurement criteria for ESG ratings yet. Moreover, research suggests that rather than using generic criteria, ESG ratings should be sector-specific, as key ESG concerns are bound to differ over sectors, such as real estate, healthcare, finance, telecommunications, and others [22]. This lack of conceptual validity leads to divergences in ratings, creating confusion both at the investor and company level and raising a call for more conceptual clarification [23,24].

\subsection{Aggregate Confusion}

Transparency and disclosure are fundamental to sustainable finance. Thus, for thirty years, information gathering and reporting have been viewed as a priority. Some wellknown initiatives include the Global Reporting Initiative (GRI), the Sustainability Accounting Standards Board (SASB), the Carbon Disclosure Project (CDP), the International Integrated Reporting Council (IIRC), and the Task Force on Climate-related Financial Disclosures (TCFD). The aim of all of these initiatives is to provide a framework by which it becomes possible to measure externalities, internalities, and the level of sustainability of a particular investment [25]. However, disclosure is only useful when one can make sense of the information disclosed. This is hampered by the divergence in ESG measurement practices.

Divergence in ratings is driven by three distinct measurement causes: divergence in scope, divergence in indicators, and divergence in aggregation rules. First, divergence in scope refers to the situation where ratings or measurements are based on different sets of attributes, such as labor practices or lobbying activities. One rating agency may include both, while another may include neither, causing ratings to diverge. Secondly, divergence in indicators means that different rating firms use different indicators to measure the same attribute, such as labor practices, again, leading to different scores. Finally, divergence in aggregation rules appears when firms attribute different weights to attributes. As these are all intertwined, it makes it difficult to interpret ratings and understand divergence in scores. For instance, Berg et al. (2019) show the category "environmental reporting" is included in ratings from Sustainalytics, RobecoSAM, Asset4, and Vigeo Eiris, but not taken into account by MSCI and KLD. Moreover, Sustainalytics uses two indicators to measure this category, while the others use only one. Finally, Sustainalytics and RobecoSAM attribute a higher weight to this category than the others.

The root cause of these differences can be explained by multiple factors. Agencies may use different metrics because of different ideologies, as mentioned earlier. More pragmatically, they can simply focus on different factors, because processing all the information contained in disclosures may be too costly [26,27]. The underlying issue here is that it is in many cases unclear which interventions benefit ESG factors to which extent, and, as such, which attributes, indicators, and weights should be applied. This makes it nearly impossible to decide which rating agency or measurement procedure is "the right one". Take Tesla, which was given a top ESG score by MSCI, ranking the company best in the global car industry; however, it simultaneously made the bottom of the FTSE's list, and ended up somewhere in the middle on Sustainalytics ESG ranking - all acclaimed rating agencies, all with different outcomes [28]. 


\subsection{A Road to Standardization}

Although "disclosing ESG issues" is increasingly seen as part of the fiduciary duties of investors, it is not at all clear what exactly should be disclosed. The plethora of existing (national) labelling schemes and requirements use different criteria to determine which economic activities qualify as sustainable, confusing investors and discouraging them from investing across borders due to difficulties in comparing different investment opportunities. This has led to wide-spread calls for standardization of ESG measurement to combat the inefficient proliferation of rating agencies and measurement standards.

The European Union (EU) has recently answered this call, publishing a new EU taxonomy classification system to start closing this gap, which is to be implemented by January 2022/2023 [29]. This process started in December 2016, when the Commission mandated a High-Level Expert Group to develop an overarching and comprehensive Union strategy on sustainable finance and ESG in order to help reach the sustainable development goals and implement the European Green Deal. By providing EU-wide appropriate definitions to companies, investors, and policymakers on what is considered sustainable, the EU hopes to enable and shift investments towards more sustainable ones.

It is important to note that "sustainable finance" is predominantly interpreted as environmental sustainability, with the current taxonomy focusing exclusively on six environmental goals. To be sure, there is a cursory mention that economic activities must comply with minimum international human and labor rights and standards to qualify as environmentally sustainable (which can be seen as a social element). Additionally, it is stated that other sustainability goals, including social objectives, will be developed at a later stage (EU/2020/852) — even noting that a report is planned for 31 December 2021 describing the provisions required to extend the scope of the regulation to include social objectives. Still, the social dimension of ESG and sustainability remain grossly neglected.

\section{Gaps in the Literature: Bringing the User Back in the Building}

The link between corporate commitment to environmental, social, and governance (ESG) issues and investment performance has generated a substantial body of research outside the real estate sector [30]. For real estate investors, it is still quite unclear which interventions can improve ESG factors in the first place and, secondly, which of those hold additional financial benefits for investors. Improving ESG is predominantly seen as matter of reducing the carbon footprint of buildings and making real estate more "green" [13,31]. A key element that is pertinently overlooked in ESG considerations is the role of the user in the building (Seyler and Mutl, 2019). This section discusses the impact of the user on the ESG rating of the building, as well as the investment value. It does so by particularly discussing the impact of user behavior on environmental sustainability (Section 3.1) as well as the concept of user wellbeing in buildings and social sustainability (Section 3.2), arguing that environmental and social sustainability go hand in hand (Section 3.3) and concluding that ESG factors and investment value can be improved through smart real estate that is user-centered (Section 3.4).

\subsection{The Environmental Dimension and User Behavior}

Environmental and energy optimizations seem to be the main drivers for the ESG evaluation of an investment. This is because energy and environmental impact has become a clear business case, which is easily expressible in monetary values [32,33]. The six main rating systems for real estate, the Building Research Establishment Environmental Assessment Methodology (BREEAM), the Comprehensive Assessment System for Built Environment Efficiency (CASBEE), the Deutsche Gesellschaft für Nachhaltiges Bauen (DGNB), the Haute Qualité Environnementale (HQETM), the Leadership in Energy and Environmental Design (LEED), and the Sustainable Building Tool (SBTool), all focus predominantly on "green" buildings and environmental impact $[33,34]$.

However, when assessing the actual impact of environmental optimizations, one important factor is often underexposed, namely, user behavior. Several studies hint towards 
an important link between user behavior and environmental performance, raising critical questions about the faith being placed in technology to reduce emissions $[35,36]$. While many technical solutions have been developed to enhance the energy efficiency in buildings, the actual effectiveness and sustainability of these solutions often do not correspond with expectations because of the missing perspective of the user's real needs and unconsidered negative side effects of their use [37-39]. Lifestyle choices make up an important part of energy usage, and, as such, the relationship between behavioral patterns and energy consumption requires more attention [40]. In order to effectively reduce the environmental impact of buildings, human behavior needs to be better understood [32].

The relationship between human behavior and sustainability can be understood as a "tragedy of the commons" [41]. This means that although people might value sustainability in general, they do not always realize the impact of their own actions, reasoning that their behavior is insignificant and has no real contribution to the problem. When everyone acts in such a way, this collective action is detrimental for the common good, in this case, the environment. As noted by Parviainen, Hansen, and Lagerström ([42], p. 155), "There is a gap between people's attitudes and feelings toward sustainability, the environment, and their own contribution.". In a speech for the Bank of England, Mark Carney ([43], p. 4) supplements this "tragedy of the commons" with the "tragedy of the horizon", stating, "The catastrophic impacts of climate change will be felt beyond the traditional horizons of most actors-imposing a cost on future generations that the current generation has no direct incentive to fix. That means beyond the business cycle, the political cycle and the horizon of technocratic authorities, like central banks". Both refer to the fact that if people will not act rationally and are not truly convinced about the long-term benefits, the system will fail, and there is no technology that can prevent that from happening.

Behavioral social science blends psychology and economics to understand how human behavior can be steered in a certain direction, without limiting choices or intervening in an overly intrusive way. This is called nudging [44]. The underlying idea is that people have "bounded rationality", meaning that when they make decisions, they do so under cognitive limitations [45]. People do not have the time and energy to gather all available information and weigh all the costs and benefits when making decisions, so too when it comes to environmentally friendly behavior. This means that even when humans would like to act sustainably, they do not always do so for a myriad of reasons. The idea of nudging is that humans' choice architecture can be designed in such a way that it nudges people in a given direction, one that would presumably make their lives better. There are examples abound of environmentally friendly nudges, such as flamboyant garbage cans to combat littering and brightly colored stairs to discourage elevator use [46]. There are also more data-driven and personalized informational nudges, such as real-time feedback on water and energy use [47]. However, large gaps remain in our understanding of how particular nudges can influence people's choices, especially in the realm of real estate $[48,49]$ and even more so when it comes to the use of technology to personalize nudges based on user behavior [50,51]. In a recent experiment, Peeters [21] showed that in an emergency situation, people tend to follow the information that they receive when escaping a real estate object. The research concludes that the integrity of the information is of crucial importance as to avoid misguiding people and leading them towards unwanted behavior. More well-designed experiments that measure the impact of smart real estate on user behavior, environmental sustainability, and cost-effectiveness over time are necessary.

\subsection{The Social Dimension and User Wellbeing}

Although sustainable investment has predominantly focused on environmental sustainability for the past two decades, the social dimension is slowly gaining more attention. While this started out with prominent ESG rating agencies (such as KLD, Sustainalytics, Vigeo Eiris, RobecoSAM, Asset4, and MSCI) including basic social rights, such as labor rights, safety, and human rights, increasingly indicators for wellness, satisfaction, and productivity are discerned [23,52]. Moreover, indicators related to environmental justice, 
such as the equal and affordable access to energy efficient buildings and social housing, could also be taken into account $[53,54]$. Although diverging measurement practices are an overall concern for ESG measurement and rating systems, conceptualizing "occupant health" or "occupant wellbeing" proves especially problematic.

To gain an overview of health and wellbeing indicators considered in current rating systems, McArthur and Powell [55] reviewed eleven global health-related rating systems. It is interesting to note that the most prominent health factors included in rating systems were building-focused themes, such as indoor air quality, thermal comfort, acoustics, and ergonomics. A great deal of research evidence specifically links these more physically tangible topics to economic and health benefits. For instance, good indoor air quality (which is consistently addressed across all reviewed rating systems) has long been proven to have a significant impact on office workers and school children, decreasing sickness absence and increasing work performance [56].

However, "softer", less tangible topics, such as diet and water, movement, social wellbeing, and psychological wellbeing, are much less consistently addressed, sometimes even despite strong scientific evidence. For instance, the health and economic benefits of drinking clean water and eating health food have long been demonstrated [57,58]. However, only four out of the eleven rating systems under study considered this in some regard (such as free and close access to water or nudges to increase water consumption), which seems like a missed opportunity.

Including themes like psychological and social well-being is more of a challenge, as there is less direct evidence for health and economic benefits. From a social science perspective, much research has been conducted to measure the user satisfaction of facility management, but proven causal relationships are scarce [59]. Schweiker et al. [60] recommend multi-dimensional field experiments to research true causality rather than big-number studies in lab-settings. The field of environmental psychology is also helpful in this regard, studying how restorative environments that promote people's health and wellbeing can be designed. The systems that do include social and psychological wellbeing predominantly focus on "biophilic" design, which has been found to have significant health benefits, including improved cognition, stress reduction, and reduced mortality rates [61]. This typically means incorporating plants and natural lighting in buildings (which is often a by-product of energy reduction and, as such, not a strictly "social" intervention). However, it seems likely that there is investment value in designing facilities that make users feel good, as this might lead to increased use of these facilities. Overall, more research is necessary regarding economically viable ways to improve user satisfaction in buildings.

\subsection{Sustainability as a Broader Concept}

Environmental psychology touches on another important point, namely that environmental and social considerations are intricately connected in a broader conceptualization of sustainability. In its early days, environmental psychology was mainly concerned with the impact of the natural, and later built, environment on humans' welfare. However, since the 1970s, the field has become increasingly focused on the interaction between humans and their environment [62], for instance, the impact of stressors caused by human behavior towards the environment, such as noise and pollution [63]. The psychology of sustainability emerged as a study of how the quality of life of inhabitants, and their physical and mental health, relates to their own attitudes towards the environment. The claim is that humans who develop a positive attitude towards the environment will also experience higher levels of wellbeing [64]. Kobal Grum writes ([64], p. 4), "It is therefore not sufficient for people to be aware of the negative impact on the environment brought by technological advancement nor is it sufficient for us to feel good in the environment in which we live. We need to know, through our behaviour, how to provide for the preservation of a healthy, safe and pleasant environment."

What is missing in the field is a focus on the built environment, which is currently neglected by researchers, planners, and users alike $[62,63]$. Sustainable psychology could 
create a reorientation towards designing real estate that protects users against environmental stress factors. There are three dimensions to this approach. First, designers should communicate more with potential users for whom the environment is being built [65]. Second, the earlier mentioned biophilic design of the built environment should be carried out, meaning that the most basic natural elements should be incorporated in built spaces. This is not only shown to be beneficial for subjective experiences but has also been proven to have a favorable impact on child development, creativity, and productivity. Finally, the built environment should be designed in an evidence-based manner [66]. This rejects fashionable, image-based design, which often leads to non-functionality, inapplicability, and, thus, dissatisfaction of users. Instead, more research is suggested on how environmental stress can be prevented and pro-environmental behavior can be promoted. As such, more research is necessary on how the built environment can be designed to promote pro-environmental behavior that removes stressors and increases user wellbeing.

The premise of the psychology of sustainability is that humans can feel empathy towards the environment. When we develop feelings of empathy towards other human beings, we care for them and, consequently, feel more satisfied and happier in doing so. Similarly, Kobal Grum [64] argues that empathy towards the environment will cause people to care for the environment more, which will subsequently improve their own quality of life and wellbeing. The impact of this behavioral change on ESG ratings and investment value needs further investigation.

\subsection{Smart as a Solution}

In order to improve ESG value (environmental and social sustainability of buildings) and investment value in real estate, the user needs to be given a more central place in the building. This can be achieved through a transition to smart real estate (indirectly indicated in, e.g., [67,68]. Although there is no agreed upon definition of smart real estate, the one provided by Ullah et al. ([69], p. 4), is especially helpful: "A property or land that uses various electronic sensors to collect and supply data to consumers, agents and real estate managers that can be used to manage assets and resources efficiently. The key features are user-centeredness, sustainability and the use of innovative and disruptive technologies in such a way as to attain holistic benefits that are otherwise not attainable". Key in this definition is the user-centeredness, which is demarcated as a necessity for smart real estate. "Smart" is not just about incorporating disruptive technology in design; it is about using technology to serve the user and elicit behavioral change [70].

User satisfaction can be improved through technology on three levels: physical, functional, and psychological. Physical satisfaction includes the physically tangible topics, discussed by McArthur and Powell [55], such as temperature, lighting, and air quality, which can be optimized, automated, and tailored through technology. Technology can also be used to improve functional satisfaction, by facilitating users' interactions with the built environment through the intelligent design of space and technology [69]. Finally, the smart integration of technology and space with users' every-day lives can support and enhance their lifestyle and needs on a psychological level. Key disruptive technologies, known as the "Big9", are the use of clouds, software, big data, IoT, drones, 3D scanning, wearable tech and gadgets, VR and AR, and AI and robotics.

Despite its potential to revolutionize the way the built environment interacts with users, smart real estate has not yet reached the main stream of real estate research or practice $[69,71-74]$. Although technology is increasingly used to improve user satisfaction on the physical and perhaps functional level, the true integration between user and building through technology has not yet been achieved. Lecomte (2019) uses the term of Cyberdasein, modelled after Heidegger's phenomenology, to describe the user who is one with the building through technology and is thus able to reach beyond the physical boundaries of the space they are in. The objective of smart real estate should be the seamless integration of physical and virtual worlds. This way, a smart building can become an active organism that engages users' senses and adapts to individualized needs and experiences. In the 
words of Chtcheglov "Everyone will live in his own personal cathedral" [74]. Similarly, Ihde [75] describes smart buildings as 'fully enclosed mini-cocoons'.

To engage meaningfully with users Heidegger's phenomenology, the study of how phenomena are experienced can prove helpful for real estate. Smart real estate is about user experience, and in the words of Weiser and Brown [76], the smart real estate experience will be to "dwell with computers". This means technology, although disruptive in its effects, should have a quiet material presence in the background, without drawing too much attention. McCullough [77] suggests an "architecture of periphery" when designing smart real estate. Users should not be disturbed by technology but immersed in it. Of course designing such "calm" technology is no mean feat, as technology often malfunctions, drawing unnecessary attention and disturbing the user experience. Technology and real estate should be made to merge seamlessly and form the user's new perception of the world (and activities as intended in the digital and virtual economy). This way, the physical boundaries of space can be overcome, and smart real estate can accommodate new forms of digital spatiality: smart space (Lecomte, 2015). Possibilities are endless in this smart space, and all the user's needs (physical, functional, and psychological) can be met. Lecomte (2019) calls this perfect harmony between user and smart space 'flow'. It is the phenomenological account of what people experience when they are fully immersed in an activity, without distractions. Flow builds on the idea that successful adoption of technology is dependent on the perceived ease of use and usefulness to a user of a technology that might elicit behavioral change [69]. Flow can thus be seen as a measure of how well technology is absorbed in space, from the center of attention to the periphery. Achieving "flow" will be the main challenge for real estate in the future.

Smart real estate thus has the potential to completely redefine how the user sees real estate and how they are influenced by the real estate object and amenities of it. In smart environments, buildings merge with technology to form "cognitive assemblages" [77], which affect users' perceptions of the world and their behavior. As such, this "smart space" becomes real estate's main productive component, whereas its physical characteristics move to the periphery of space users' attention. Consequently, Lecomte (2019) suggests adding "digital" as a fifth dimension to Graaskamp's [78] seminal framework next to height, width, length, and time. The value of real estate is no longer simply determined by square footage or cost per year but additionally by the digital "flow" that a building is able to produce. Differences in ability to produce flow are likely to become a key value indicator for future real estate, not in the least through its effect on ESG factors when performing investment analysis. Making real estate user centered, and thus a consumer product, could lead to hedonic pricing. In this scenario, the user's behavior will determine the value of the object from its utility. Measuring this experienced utility is often seen as an important obstacle. However, Kahneman et al. [79] suggest deriving utility from reports of experience or psychological indices. Alternatively, Ullah et al. [69] advocate following the technology adoption model (TAM) that measures the use and acceptance of technology through factors such as perceived usefulness, perceived ease of use, user satisfaction, behavioral intention to use, and actual use. Furthermore, smart technologies can not only be adapted to create utility for users but also assist in collecting and analyzing data to measure utility. To be sure, besides being a source of opportunity, user centricity may also be a source of challenges. Real estate players will have to identify how to capture value from space users' dual experiences of physical and digital space in smart real estate (Lecomte, 2019). Moreover, although the value of disruptive technology is widely acknowledged, its adoption and usage remain limited in practice [69].

\section{Conclusions and Discussion}

Investors are increasingly required to report on environment, social, and governance (ESG) issues as part of their fiduciary duty. As such, finding sustainable investments that also present a good business case is paramount. A substantial body of research has focused on understanding the relationship between financial and nonfinancial investment perfor- 
mance, although findings regarding real estate investment carry mixed and contradictory findings [5,9], not in the least because there is no clear definition of ESG. One important oversight in most ESG conceptualizations is the complete neglect of user behavior, which is especially relevant for sustainable real estate investments. As such, the user needs to be brought back into the building.

This article has shown that, firstly, it is important to factor in user behavior when trying to reduce the environmental impact of buildings. Behavioral social science teaches us that users can be nudged in subtle ways to act in more environmentally conscious ways [44]. However, more research out of lab settings is warranted to explore which nudges can steer behavior effectively while also presenting a sound business case. Data-driven technological nudges present an especially interesting case for further exploration. Secondly, the social dimension of ESG is strongly underconceptualized and should include more elements of user wellbeing. This will not only lead to improved user satisfaction, but early research tentatively suggests that interventions to improve wellbeing might also increase investment returns. However, this remains to be tested. Moreover, social and environmental wellbeing are intricately linked, but they are typically treated separately. The current literature on environmental psychology suggests that in order to feel good, we need to engage in environmentally sustainable behavior and create a healthy environment [64]. However, environmental psychology focused on the built environment is still in its early stages, and much is left to be understood about these interrelations in real-world situations.

To bring the user back in the building, the article suggests a transition to smart real estate. To be sure, making a building "smart" is not just about incorporating disruptive technology in design but using technology to serve the user and elicit behavioral change [47,70]. However, there is a gap with respect to real business cases and in-field experiments on the impact of digitalization on sustainability in real estate and its effect on real estate investments. Data-driven informational nudging holds strong potential here [47], but the field remains largely underdeveloped. Alternatively, much work remains in finding ways to introduce "disruptive" (innovative) technology that does not disrupt user experience. Early research findings suggest that technology must remain at the periphery of built spaces in order to create an enjoyable "flow" for users [74]. It is precisely this "flow" that is suggested to be a key predictor of real estate value in the future.

The literature shows an apparent link between smart and sustainable real estate and the digital economy. However, in practice today, digitalization is not being explicitly considered when evaluating real estate and its ESG factors. A seminal question for future research and practice in real estate will be how sustainable real estate can be facilitated through technology, with key questions being the following: What kind of technology will be used? Who as a stakeholder is affected directly by it? How are these stakeholders affected in terms of processes and dissemination mechanisms? Related questions that are bound to surface will inevitably include ethical and regulatory challenges in using data to improve user wellbeing and steer user behavior.

Given the diverging measurements of ESG factors, as well as their important shortcomings, especially in the social realm and with regard to technological innovation, practitioners and academics are encouraged to critically evaluate and contextualize the ESG framework they are using as well as the extent to which users are considered and smart technology is employed.

Author Contributions: S.K.: Conceptualization, writing—original draft preparation; M.P.: conceptualization, writing—reviewing and editing; T.C.: writing—reviewing and editing. All authors have read and agreed to the published version of the manuscript.

Funding: This research received no external funding.

Conflicts of Interest: The authors declare no conflict of interest. 


\section{References}

1. Dorfleitner, G.; Halbritter, G.; Nguyen, M. Measuring the level and risk of corporate responsibility-An empirical comparison of different ESG rating approaches. J. Asset Manag. 2015, 16, 450-466. [CrossRef]

2. Eccles, R.G.; Lee, L.-E.; Stroehle, J.C. The Social Origins of ESG: An Analysis of Innovest and KLD. Organ. Environ. 2020, 33, 575-596. [CrossRef]

3. UNEP-FI. Fiduciary Duty in the 21st Century. 2019. Available online: https://www.unepfi.org/publications/investmentpublications / fiduciary-duty-in-the-21st-century-final-report/ (accessed on 20 January 2021).

4. Wong, W.C.; Batten, J.A.; Ahmad, A.H.; Mohamed-Arshad, S.B.; Nordin, S.; Adzis, A.A. Does ESG certification add firm value? Financ. Res. Lett. 2021, 39, 101593. [CrossRef]

5. Cajias, M.; Fuerst, F.; McAllister, P.; Nanda, A. Do responsible real estate companies outperform their peers? Int. J. Strat. Prop. Manag. 2014, 18, 11-27. [CrossRef]

6. Xie, J.; Nozawa, W.; Yagi, M.; Fujii, H.; Managi, S. Do environmental, social, and governance activities improve corporate financial performance? Bus. Strat. Environ. 2019, 28, 286-300. [CrossRef]

7. Abdi, Y.; Li, X.; Càmara-Turull, X. Impact of Sustainability on Firm Value and Financial Performance in the Air Transport Industry. Sustain. J. Rec. 2020, 12, 9957. [CrossRef]

8. Signori, S.; San-Jose, L.; Retolaza, J.L.; Rusconi, G. Stakeholder Value Creation: Comparing ESG and Value Added in European Companies. Sustain. J. Rec. 2021, 13, 1392. [CrossRef]

9. Hebb, T.; Hamilton, A.; Hachigian, H. Responsible Property Investing in Canada: Factoring Both Environmental and Social Impacts in the Canadian Real Estate Market. J. Bus. Ethic. 2010, 92, 99-115. [CrossRef]

10. Siew, R.Y.; Balatbat, M.C.; Carmichael, D.G. The relationship between sustainability practices and financial performance of construction companies. Smart Sustain. Built Environ. 2013, 2, 6-27. [CrossRef]

11. Holtermans, R.; Kok, N. On the Value of Environmental Certification in the Commercial Real Estate Market. Real Estate Econ. 2017, 47, 685-722. [CrossRef]

12. Alareeni, B.A.; Hamdan, A. ESG impact on performance of US S\&P 500-listed firms. Corp. Gov. Int. J. Bus. Soc. 2020, 20, 1409-1428. [CrossRef]

13. Marzuki, M.J.; Newell, G. The evolution of Belgium REITs. J. Prop. Investig. Financ. 2019, 37, 345-362. [CrossRef]

14. Nekhili, M.; Boukadhaba, A.; Nagati, H. The ESG-financial performance relationship: Does the type of employee board representation matter? Corp. Gov. Int. Rev. 2020, 12345. [CrossRef]

15. Kuykendall, J. 5 Year Analysis of Company ESG Ratings Verses Financial Performance. Ph.D. Thesis, University of Nevada, Reno, NV, USA, 2019.

16. Auer, B.R.; Schuhmacher, F. Do socially (ir)responsible investments pay? New evidence from international ESG data. Q. Rev. Econ. Financ. 2016, 59, 51-62. [CrossRef]

17. Lu, W.; Ye, M.; Chau, K.; Flanagan, R. The paradoxical nexus between corporate social responsibility and sustainable financial performance: Evidence from the international construction business. Corp. Soc. Responsib. Environ. Manag. 2018, $25,844-852$. [CrossRef]

18. Friede, G.; Busch, T.; Bassen, A. ESG and financial performance: Aggregated evidence from more than 2000 empirical studies. J. Sustain. Financ. Investig. 2015, 5, 210-233. [CrossRef]

19. Veenstra, E.M.; Ellemers, N. ESG Indicators as Organizational Performance Goals: Do Rating Agencies Encourage a Holistic Approach? Sustain. J. Rec. 2020, 12, 10228. [CrossRef]

20. Glass, J.; Glass, J. The state of sustainability reporting in the construction sector. Smart Sustain. Built Environ. 2012, 1, 87-104. [CrossRef]

21. Peeters, M.; Compernolle, T.; Van Passel, S. Influence of information provided at the moment of a fire alarm on the choice of exit. Fire Saf. J. 2020, 117, 103221. [CrossRef]

22. Halbritter, G.; Dorfleitner, G. The wages of social responsibility-where are they? A critical review of ESG investing. Rev. Financial Econ. 2015, 26, 25-35. [CrossRef]

23. Berg, F.; Kölbel, J.F.; Rigobon, R. Aggregate Confusion: The Divergence of ESG Ratings. SSRN Electron. J. 2019. [CrossRef]

24. Leiringer, R. Sustainable Construction through Industry Self-Regulation: The Development and Role of Building Environmental Assessment Methods in Achieving Green Building. Sustain. J. Rec. 2020, 12, 8853. [CrossRef]

25. University of Cambridge Institute for Sustainability CISL. Module 3 Unit 2 Disclosure, Scalability and Drivers for Change, in Course on Sustainability Leadership, Module 3 Unit 2, 2020. Available online: https:/ /www.cisl.cam.ac.uk/education/learnonline (accessed on 20 January 2021).

26. Merton, R.C. A Simple Model of Capital Market Equilibrium with Incomplete Information. J. Financ. 1987, 42, 483-510. [CrossRef]

27. Bonsall, S.B.; Miller, B.P. The impact of narrative disclosure readability on bond ratings and the cost of debt. Rev. Account. Stud. 2017, 22, 608-643. [CrossRef]

28. Van Hamme, K. Goede Bedoelingen Zijn Geen Goede Beleggingen. De Tijd, 16 March 2019.

29. Regulation (EU) 2020/852. Regulation (EU) 2020/852 of the European Parliament and of the Council of 18 June 2020 on the Establishment of a Framework to Facilitate Sustainable Investment, and Amending Regulation (EU) 2019/2088. Available online: https:/ / eur-lex.europa.eu/legal-content/EN/TXT/?uri=celex:32020R0852 (accessed on 20 January 2021). 
30. Cajias, M.; Fuerst, F.; McAllister, P.; Nanda, A. Is ESG Commitment Linked to Investment Performance in the Real Estate Sector? 2011. Available online: https://ideas.repec.org/p/arz/wpaper/eres2011_118.html (accessed on 20 January 2021).

31. Bauer, R.; Eichholtz, P.M.A.; Kok, N.; Quigley, J.M. How Green is Your Property Portfolio? The Global Real Estate Sustainability Benchmark. Rotman Int. J. Pension Manag. 2011, 4, 34-43.

32. Seyler, N.J.; Mutl, J. Going beyond buildings: Mindfulness and real estate user behavior. J. Corp. Real Estate 2019, $21,194-211$. [CrossRef]

33. Bernardi, E.; Carlucci, S.; Cornaro, C.; Bohne, R.A. An Analysis of the Most Adopted Rating Systems for Assessing the Environmental Impact of Buildings. Sustain. J. Rec. 2017, 9, 1226. [CrossRef]

34. Cordero, A.S.; Melgar, S.G.; Márquez, J.M.A. Green Building Rating Systems and the New Framework Level(s): A Critical Review of Sustainability Certification within Europe. Energies 2019, 13, 66. [CrossRef]

35. Bull, R.; Azennoud, M. Smart citizens for smart cities: Participating in the future. Proc. Inst. Civ. Eng. Energy 2016, 169, 93-101. [CrossRef]

36. Thomsen, J.; Berker, T.; Lappegard Hauge, Å.; Denizou, K.; Wågø, S.I.; Jerkø, S. The interaction between building and users in passive and zero-energy housing and offices: The role of interfaces, knowledge and user commitment. Smart Sustain. Built Environ. 2013, 2, 43-59. [CrossRef]

37. Baedeker, C.; Piwowar, J.; Themann, P.; Grinewitschus, V.; Krisemendt, B.; Lepper, K.; Zimmer, C.; Von Geibler, J. Interactive Design to Encourage Energy Efficiency in Offices: Developing and Testing a User-Centered Building Management System Based on a Living Lab Approach. Sustain. J. Rec. 2020, 12, 6956. [CrossRef]

38. Delzendeh, E.; Wu, S.; Lee, A.; Zhou, Y. The impact of occupants' behaviours on building energy analysis: A research review. Renew. Sustain. Energy Rev. 2017, 80, 1061-1071. [CrossRef]

39. Meistad, T. How energy efficient office buildings challenge and contribute to usability. Smart Sustain. Built Environ. 2014, 3, 110-131. [CrossRef]

40. Chen, C.; Cook, D.J.; Crandall, A.S. The user side of sustainability: Modeling behavior and energy usage in the home. Pervasive Mob. Comput. 2013, 9, 161-175. [CrossRef]

41. Hardin, G. The Tragedy of the Commons Garrett Hardin. Science 1968, 162, 1243-1248.

42. Parviainen, E.; Lagerström, E.; Hansen, P. Transform Your Kids into Self Sustainable Power Plants. In DIS '17 Companion: Proceedings of the 2016 ACM Conference Companion Publication on Designing Interactive Systems, Brisbane, QLD, Australia, 4-8 June 2016; Association for Computing Machinery (ACM): New York, NY, USA, 2017; pp. 155-160.

43. Carney, M. Breaking the Tragedy of the Horizon-Climate Change and Financial Stability. 2015. Available online: https://www. bankofengland.co.uk/speech/2015/breaking-the-tragedy-of-the-horizon-climate-change-and-financial-stability (accessed on 20 January 2021).

44. Thaler, R.H.; Sunstein, C.R. Nudge: Improving Decisions About Health, Wealth, and Happiness; Penguin Books: London, UK, 2009.

45. Simon, H.A. Bounded Rationality. In Utility and Probability; Palgrave Macmillan: London, UK, 1990; pp. 15-18.

46. Bicchieri, C.; Dimant, E. Nudging with Care: The Risks and Benefits of Social Information. Public Choice 2019. [CrossRef]

47. Ranchordás, S. Nudging citizens through technology in smart cities. Int. Rev. Law Comput. Technol. 2019, 34, 254-276. [CrossRef]

48. Byerly, H.; Balmford, A.; Ferraro, P.J.; Wagner, C.H.; Palchak, E.; Polasky, S.; Ricketts, T.H.; Schwartz, A.J.; Fisher, B. Nudging pro-environmental behavior: Evidence and opportunities. Front. Ecol. Environ. 2018, 16, 159-168. [CrossRef]

49. Coskun, A.; Erbug, C. User Orientation Maps: An Approach to Address User Diversity in Design for Sustainable Behaviour. Des. J. 2016, 20, 131-152. [CrossRef]

50. Dubman, R. The Digital Governance of Data-driven Smart Cities: Sustainable Urban Development, Big Data Management, and the Cognitive Internet of Things. Geopolit. Hist. Int. Relat. 2019, 11, 34-40.

51. Irizar-Arrieta, A.; Casado-Mansilla, D.; Garaizar, P.; López-De-Ipiña, D.; Retegi, A. User perspectives in the design of interactive everyday objects for sustainable behaviour. Int. J. Hum. Comput. Stud. 2020, 137, 102393. [CrossRef]

52. Driza, P.-J.N.; Park, N.-K. Occupant satisfaction in LEED-certified higher education buildings. Smart Sustain. Built Environ. 2014, 3, 223-236. [CrossRef]

53. Gianfrate, V.; Piccardo, C.; Longo, D.; Giachetta, A. Rethinking social housing: Behavioural patterns and technological innovations. Sustain. Cities Soc. 2017, 33, 102-112. [CrossRef]

54. Du, X.; Zhang, X.; Wang, H.; Zhi, X.; Huang, J. Assessing Green Space Potential Accessibility through Urban Artificial Building Data in Nanjing, China. Sustain. J. Rec. 2020, 12, 9935. [CrossRef]

55. McArthur, J.; Powell, C. Health and wellness in commercial buildings: Systematic review of sustainable building rating systems and alignment with contemporary research. Build. Environ. 2020, 171, 106635. [CrossRef]

56. Wargocki, P.; Wyon, D.P. Ten questions concerning thermal and indoor air quality effects on the performance of office work and schoolwork. Build. Environ. 2017, 112, 359-366. [CrossRef]

57. Popkin, B.M.; D'Anci, K.E.; Rosenberg, I.H. Water, hydration, and health. Nutr. Rev. 2010, 68, 439-458. [CrossRef]

58. Slavin, J.L.; Lloyd, B. Health Benefits of Fruits and Vegetables. Adv. Nutr. 2012, 3, 506-516. [CrossRef]

59. Grum, B.B. Impact of facilities maintenance on user satisfaction. Facilities 2017, 35, 405-421. [CrossRef]

60. Schweiker, M.; Ampatzi, E.; Andargie, M.S.; Andersen, R.K.; Azar, E.; Barthelmes, V.M.; Berger, C.; Bourikas, L.; Carlucci, S.; Chinazzo, G.; et al. Review of multi-domain approaches to indoor environmental perception and behaviour. Build. Environ. 2020, 176, 106804. [CrossRef] 
61. Gillis, K.; Gatersleben, B. A Review of Psychological Literature on the Health and Wellbeing Benefits of Biophilic Design. Buildings 2015, 5, 948-963. [CrossRef]

62. Sörqvist, P. Grand Challenges in Environmental Psychology. Front. Psychol. 2016, 7, 583. [CrossRef]

63. Lindvall, T. On sensory evaluation of odorous air pollutant intensities. Nord. Hyg. Tidskr. 1970. [CrossRef]

64. Grum, D.K. Interactions between human behaviour and the built environment in terms of facility management. Facilities 2018, 36, 2-12. [CrossRef]

65. Sommer, R. Social Design: Creating Buildings with People in Mind; Prentice-Hall: Upper Saddle River, NJ, USA, 1983.

66. McCunn, L.J.; Gifford, R. Environmental Design in Acute Care Settings: A Case Study of a Neurological Rehabilitation Unit. HERD Health Environ. Res. Des. J. 2013, 7, 102-113. [CrossRef] [PubMed]

67. Moreno, M.V.; Zamora, M.A.; Skarmeta, A.F. User-centric smart buildings for energy sustainable smart cities. Trans. Emerg. Telecommun. Technol. 2014, 25, 41-55. [CrossRef]

68. Papagiannidis, S.; Marikyan, D. Smart offices: A productivity and well-being perspective. Int. J. Inf. Manag. 2020, 51, 102027. [CrossRef]

69. Ullah, F.; Sepasgozar, S.M.E.; Wang, C. A Systematic Review of Smart Real Estate Technology: Drivers of, and Barriers to, the Use of Digital Disruptive Technologies and Online Platforms. Sustain. J. Rec. 2018, 10, 3142. [CrossRef]

70. Curry, E.; Sheth, A. Next-Generation Smart Environments: From System of Systems to Data Ecosystems. IEEE Intell. Syst. 2018, 33, 69-76. [CrossRef]

71. Apanaviciene, R.; Urbonas, R.; Fokaides, P.A. Smart Building Integration into a Smart City: Comparative Study of Real Estate Development. Sustain. J. Rec. 2020, 12, 9376. [CrossRef]

72. Ghansah, F.A.; Owusu-Manu, D.-G.; Ayarkwa, J.; Darko, A.; Edwards, D.J. Underlying indicators for measuring smartness of buildings in the construction industry. Smart Sustain. Built Environ. 2020. [CrossRef]

73. Gijsbers, R.; Lichtenberg, J.J.N. Demand driven selection of adaptable building technologies for flexibility-in-use. Smart Sustain. Built Environ. 2014, 3, 237-260. [CrossRef]

74. LeComte, P. iSpace: Principles for a phenomenology of space user in smart real estate. J. Prop. Investig. Financ. 2019, 38, 271-290. [CrossRef]

75. Ihde, D. Technology and the Lifeworld: From Garden to Earth; Indiana University Press: Bloomington, India, 1990.

76. Weiser, M.; Brown, J.S. Designing Calm Technology. PowerGrid J. 1996, 1, 75-85.

77. McCullough, M. Digital Ground: Architecture, Pervasive Computing, and Environmental Knowing; MIT Press: Cambridge, MA, USA, 2004.

78. Graaskamp, J.A. Fundamentals of real estate development. Risk Manag. 1981, 10, 1-31. [CrossRef]

79. Kahneman, D.; Wakker, P.; Sarin, R. Back to Bentham? Explorations of Experienced Utility. Q. J. Econ. 1997, 112, 375-406. [CrossRef] 